Anna Walulik*

Janusz Krysztofik**

Kraków

\title{
Otwarta sesja Komitetu Nauk Pedagogicznych Polskiej Akademii Nauk Toruń, 26 czerwca 2012 roku
}

W ponowoczesnej atmosferze braku stałych punktów odniesienia poszukiwanie tożsamości jest coraz bardziej aktualnym zadaniem, a może wręcz wyzwaniem. W odpowiedzi na nie w dniu 26 czerwca 2012 roku Komitet Nauk Pedagogicznych Polskiej Akademii Nauk na otwartej sesji podjął problematykę jakości badań naukowych w pedagogice. Obrady odbywały się na Wydziale Nauk Pedagogicznych Uniwersytetu Mikołaja Kopernika w Toruniu. Wystapienia i dyskusja koncentrowały się na poszukiwaniu standardów i prezentacji dobrych praktyk w badaniach pedagogicznych. Gospodarzem spotkania był Dziekan Wydziału - prof. zw. dr hab. Aleksander Nalaskowski.

W przeświadczeniu, że człowiek uczy się na błędach i to najlepiej na własnych, prof. zw. dr hab. Bogusław Śliwerski - przewodniczący Komitetu Nauk Pedagogicznych Polskiej Akademii Nauk - zaproponował krytyczną dyskusję nad awansowymi koncepcjami badawczymi i wnioskami składanymi do Narodowego Centrum Nauki. W wystapieniu o nieco prowokującym tytule: Diagnoza kompromitujących błędów metodologicznych $w$ koncepcjach (wnioskach) badań pedagogicznych, przedstawiona została diagnoza osiagnięć i porażek naukowych w pedagogice oraz pułapki, w które najłatwiej wpaść na drodze awansu naukowego. Są nimi najczęściej:

* S. dr Anna Walulik CSFN jest pracownikiem Akademii Ignatianum w Krakowie.

** Dr Janusz Krysztofik jest pracownikiem Instytutu Zarządzania Wiedzą w Krakowie. 
- negatywna ocena rozprawy habilitacyjnej, mimo pozytywnej oceny wydawniczej książki habilitacyjnej;

- zbyt mała liczba publikacji naukowych w dorobku podoktorskim;

- różnice w ocenie przyjętego paradygmatu badań między recenzentami.

W negatywnych recenzjach dorobku habilitacyjnego zwykle uwagi recenzentów dotyczą takich kwestii, jak:

- ,produkowania informacji o informacji”;

- braku określonej metodologii badań;

- braku kwestii teoriopoznawczych;

- wątpliwego wkładu w naukę;

- naiwnej, wręcz zwulgaryzowanej wizji humanistyki;

- nieznajomości podstawowej literatury;

- braku twórczej inwencji;

- zasłaniania się autorytetami;

- tez pozbawionych uzasadnienia;

- asymetrii dorobku naukowego.

Profesor Śliwerski dokonał liczbowego zestawienia złożonych wniosków habilitacyjnych i profesorskich z pedagogiki, zarówno w Polsce, jak i na Słowacji. Zwrócił uwagę na fakt, że w Polsce, inaczej niż na Słowacji, nie ma możliwości uzyskania habilitacji z metodyki oraz na istniejące rozbieżności w nomenklaturze dyscyplin naukowych, w których nadawane są tytuły.

Z kolei analiza wniosków składanych do Narodowego Centrum Nauki uświadamia, że największy problem, z jakim zmagają się ich autorzy, dotyczy konceptualizacji badań. W tym kontekście postawione zostało pytanie: jakich unikać błędów, by było lepiej? Dyskusję rozpoczął prof. zw. dr hab. Krzysztof Rubacha, który jako Prodziekan Wydziału Nauk Pedagogicznych Uniwersytetu Mikołaja Kopernika w Toruniu był nie tylko współorganizatorem tego spotkania, ale także jego merytorycznym inicjatorem. Profesor Rubacha, zachęcając do refleksji nad badaniami prowadzonymi przez pedagogów, podkreślał, że ich wartość wyjaśniająca zależy w dużym stopniu od jakości podstaw metodologicznych. Przypomniał o trzech zasadniczych etapach badań naukowych, jakimi są: konceptualizacja, problematyzacja i analiza. Stanowią one podstawę dyskusji nad standardami metodologicznymi, które determinują praktykę stojącą za projektami, ale nie mogą ograniczać poszczególnych podejść badawczych. Profesor Rubacha podkreślał, że rzeczywistość wychowawcza istnieje o tyle, o ile autor badań nada jej znaczenie. Dlatego definiowanie zmiennych musi respektować założenia metodologiczne, a analiza przedmiotu dotyczyć problemu badania. Wyznaczać go powinna krytyczna ocena rzeczywistości, w wyniku której będzie możliwe 
znalezienie „luki” wymagającej wyjaśnienia. Taka problematyzacja stwarza szansę głębszego koncentrowania się na zagadnieniach centralnych dla pedagogiki, zarówno na poziomie badań stosowanych, jak i podstawowych. W tym kontekście niepokojące są spostrzeżenia z analizy wniosków składanych do Narodowego Centrum Nauki. Wynika z niej, że duża część polskich naukowców w dyscyplinie pedagogiki prezentuje niski poziom kompetencji metodologicznej, co w konsekwencji sprawia, że niekoniecznie promowane są granty wysokiej jakości, a rady wydziałów bezkrytycznie otwierają przewody naukowe.

Recenzenci wielokrotnie stwierdzają, że autor projektu nie wykazał się znajomością literatury dotyczącej problemu z obszaru badań i co więcej sam przyznaje, że uzupełni tę lukę dopiero po przygotowaniu projektu i nie przeszkadza mu to w twierdzeniu, że takich badań w zasadzie nie ma. W odniesieniu do projektu badawczego recenzenci oceniają że jest on dość słabo osadzony w teorii i niewystarczająco uzasadniony teoretycznie. Ponadto jest on teoretyczny albo eklektyczny i oparty na sprzeczności paradygmatycznej. Przedkładane projekty są postrzegane jako mało oryginalne. Autorzy zamierzają weryfikować znane poglądy i niewiele wnoszą do nauki. W ocenianych projektach badawczych często brakuje odniesień do wcześniejszych badań, spójności pomiędzy: tematem - słowami kluczowymi a deklarowanymi efektami oraz danych pozwalających z większą dozą optymizmu zakładać wykonalność tematu.

W odniesieniu do konceptualizacji projektu uwagi recenzentów dotyczą braku podstaw do wyboru narzędzi badań i sensownych interpretacji uzyskanego materiału empirycznego. W aspekcie dojrzałości naukowej recenzenci stwierdzaja, że zdrowy rozsądek i wiedza potoczna niepoddane żadnym rygorom myślenia nie są $\mathrm{w}$ stanie dostarczyć materiału wartościowego pod względem poznawczym, a opisy programu badań nie wykraczają poza ramy pojęciowe, które dziś dla pedagogiki mają znaczenie głównie historyczne. Odnosząc się do formułowanych wniosków i opracowań, recenzenci zwracają uwagę na to, że język opisu nie jest naukowy. Zastapiła go ideologia i „westchnienia” autora. Często jest zbiorem stereotypów i potocznych sformułowań, niepopartych literatura przedmiotu. Spostrzeżenia te wyznaczają główne przyczyny dyskwalifikacji w Narodowym Centrum Nauki projektów z pedagogiki. Można uznać, że nie uzyskują one akceptacji ze względu na:

- banalne tematy;

- jałowość poznawczą, wynikającą z naiwnego założenia;

- treść projektu tylko częściowo jest związana z jego tytułem;

- brak w tytule rozstrzygnięć, czy są to badania metateoretyczne czy praktyczne. 
Profesor Rubacha wyraził nadzieję, że wzięcie pod uwagę wniosków wypływających z analizy nadsyłanych do Narodowego Centrum Nauki projektów może przyczynić się do podniesienia jakości i w konsekwencji większej skuteczności w zakwalifikowaniu ich do finansowania.

Następne wystąpienia dostarczały kolejnych impulsów do dyskusji. Prof. zw. dr hab. Aleksandrer Nalaskowski - Dziekan Wydziału Nauk Pedagogicznych UMK w Toruniu, analizował przyczyny ,autowania” się pedagogiki. Zastanawiał się, dlaczego:

jak mantrę, z generacji na generację powielamy niezrozumiałe zupełnie kompleksy. Pedagogika wydaje się być dyscypliną, która pod względem samokrytycyzmu, obecnego głównie na konferencjach i wręcz masochistycznego znęcania się nad sobą, nie ma sobie równych! Tutaj osiagnęliśmy chyba mistrzostwo świata. Tymczasem, jest to moja teza wyjściowa, nikt tak dobrze jak my nie rozumie współczesności i zachodzących w niej procesów. Nikt tak dobrze jak my nie rozumnie, że w życiu nie ma prostych recept.

Za główne przyczyny tego stanu rzeczy uznał, obok kompleksów, system parametryzacji osiagnięć naukowych i kwestię wprowadzania w praktykę osiagnięć teoretycznych.

Z kolei prof. zw. dr hab. Zbigniew Kwieciński zaprezentował badania dynamiczne realizowane przez zespół toruński jako swoiste dla pedagogiki. Dokonując ich kategoryzacji podkreślał konieczność uwzględnienia w badaniach specyfiki metodologicznej tej dyscypliny naukowej. Podkreślał, że „W każdym badaniu pedagogicznym występują złożone kompleksy metod i technik badawczych, które są jednocześnie podejściem hermeneutycznym, empirycznym i prakseologicznym".

Problematykę paradygmatyczności $\mathrm{w}$ badaniach, zasygnalizowaną przez Profesora Rubachę, podjął w swoim wystapieniu prof. zw. dr hab. Mieczysław Malewski, który w referacie pod tytułem: Metodologia badań społecznych - ortodoksja i refleksja, uzasadniał tezę, że: „Na przestrzeni ostatniego ćwierćwiecza w metodologii nauk społecznych ma miejsce cicha rewolucja. Obowiązująca dotychczas racjonalność internalna jest zastępowana racjonalnością eksternalną". Profesor Malewski wyjaśniał, że najnowszy spór o metodę naukową toczy się obecnie na kanwie praktyk badawczych łączących badania ilościowe i jakościowe. Podkreślał, że wyznawcy kartezjańskiego stanowiska, które zakłada jednolity charakter metody naukowej, głoszą pogląd, że badania ilościowe i jakościowe są jak najbardziej komplementarne. Posługują się w nim trojakiego rodzaju argumentacją. Pierwszy polega na wykazaniu pozornych różnic między badaniami ilościowymi i jakościowymi. Listę pełną pozornych różnic przedstawił znany współcześnie 
metodolog Martyn Hammersley. Drugi typ argumentacji wykazującej, że badania ilościowe i jakościowe są komplementarne, polega na przedstawianiu metod ilościowych i jakościowych na kontinuum. Używa się go do wykazania pozorności różnic między nimi. Jako przykład wskazał kontinuum: ankieta, ankieta audytoryjna, wywiad skategoryzowany, wywiad swobodny, wywiad narracyjny. Podkreślał, że takie kontinuum zaciera różnice. Trzecią strategia jest zabieg redukcji samego pojęcia „metodologia”, który polega na zawężeniu jego zakresu do poziomu metod i technik badawczych. W ten sposób zostaje ono wypreparowane z kontekstu ontologicznego i epistemologicznego. Profesor Malewski zwracał uwagę na to, że miejsce paradygmatu zajmuje coraz częściej tak zwana perspektywa badawcza, która ze swej natury jest uprawomocniona badawczo. Zmiana ta dokonuje się analogicznie do ponowoczesnych przeobrażeń społeczno-kulturowych, które obejmuja „usieciowienie”, powstawanie nowych ruchów społecznych oraz postępującą indywidualizację społeczną. W jej wyniku wiedza „wytwarzana” jest dla zmiany społecznej. Zjawisko to w badaniach naukowych ilustruje poszukiwanie komplementarności poprzez łączenie odmiennych opcji paradygmatycznych. W praktyce oznacza to między innymi tworzenie hybrydowych modeli badań.

W kolejnych wystapieniach uczestnicy obrad mieli możliwość refleksji nad urzeczywistnieniem rozważanych problemów teoretycznych w praktyce badawczej. Prof. dr hab. Bogusława Dorota Gołębniak ukazała możliwości, jakie dają pedagogice badania interwencyjne, czyli badania w działaniu. W wystapieniu pod tytułem: Badania interwencyjne - podstawy akademickiej legitymizacji a/i realizacyjne wypaczenia, prelegentka zwróciła uwagę na potrzebę „dekolonizacji akademii” wynikającą z nowej funkcji nauki. Profesor Gołębniak dzieliła się swoim doświadczeniem odnośnie do rozumienia funkcji nauki. Wyjaśniała, że badania naukowe są obecne w różnych miejscach, w różnych grupach i różnych wspólnotach, które niekoniecznie mają związek z tak zwaną , „akademią” i niekoniecznie prowadzone są przez badaczy profesjonalnie przygotowanych lub posiadających doświadczenia w realizacji tego typu projektów. Pierwsze pytanie o dekolonizację akademii polega na ustaleniu, kto i jak prowadzi badania interwencyjne. Bardzo ważne jest odkrycie, że myślenie o badaniach traktowanych jako praktyka społeczna jest działaniem etycznym i moralnym.

Zdaniem Profesor Gołębniak, w literaturze powstał termin „śmietnik” - nie w znaczeniu pejoratywnym, lecz takim, które jest jednym ze wskaźników dekolonizacji akademii. Pozwala on na uznawanie źródeł w wielu konwencjach, takich jak: poezja, dramat, fotografia, film, a nie tylko w tekstach stricte naukowych. Raporty z tego typu badań nie są klasycznymi raportami $\mathrm{z}$ badań naukowych. 
Z kolei dr hab. Mirosława Dziemianowicz-Nowak, prof. DSW, zaproponowała rozważania nad możliwościami badań narracyjnych z perspektywy pedagoga. Uznała, że punktem wyjścia w podejmowaniu tego typu podejść musi być pytanie o ontologię i epistemologię, gdyż świat nie składa się z „następstw”. Badacz powinien nadać im osobiste znaczenia, ustanowić sensy, określić możliwości poznania i odkryć reguły, zgodnie z którymi doświadczenia są konstruowane. Wynika to z przekonania, że człowiek nie tylko opowiada o życiu, ale jest jego „rezultatem”. Badania narracyjne dają wiele możliwości interpretowania sytuacji wychowawczej. Nie chodzi w nich bowiem tylko o zobaczenie, „kto mówi i z jakiej pozycji”, ale także o odkrywanie „kto nie mówi i o czym nie mówi”.

Serię wystąpień Profesorów zakończył panel Zadaniowego Zespołu Samokształceniowego Doktorów KNP PAN na temat umiejętności pisania prac naukowych, któremu przewodniczyła prof. zw. dr hab. Maria Dudzikowa. Jego uczestnicy poszukiwali odpowiedzi na pytania: Jak bywa? Jak powinno być? Co możemy zrobić w tych warunkach? Były one rozpatrywane $\mathrm{z}$ różnych perspektyw, między innymi z perspektywy studentów, doktorantów i młodych doktorów. Wybrzmiewało w nich poczucie zagubienia w niejednoznacznych koncepcjach metodologicznych i potrzeba wsparcia ze strony doświadczonych pracowników naukowych.

Wystapienia stanowiły teoretyczne rozważania nad możliwością podnoszenia jakości badań pedagogicznych, które uzupełnione zostały cennymi głosami w dyskusji. Prof. dr hab. Barbara Theiss wskazała na konieczność budowania wewnętrznego kapitału społecznego środowiska pedagogów i szukanie autorytetu pedagogiki. Prof. dr hab. Tomasz Szkudlarek wręcz zaapelował do środowiska o zaangażowanie w przygotowywanie projektów badawczych do konkursów ogłaszanych przez Narodowe Centrum Nauki. Nie powinna $\mathrm{w}$ tym przeszkodzić negatywna, nawet krzywdząca i merytorycznie nieuzasadniona ocena recenzentów. Na problem recenzowania projektów konkursowych zwrócił uwagę prof. zw. dr hab. Ryszard Borowicz. Podkreślił, że rzetelność i wysoki poziom merytoryczny recenzji stanowi istotną drogę w podnoszeniu jakości badań naukowych w pedagogice.

Na zakończenie obrad wręczona została przez Redaktora Naczelnego czasopisma „Kultura i Edukacja” nagroda dla laureata VI Edycji Konkursu „Kultury i Edukacji” na najlepszą monografię podejmującą problematykę kultury, społeczeństwa i edukacji. Warto zauważyć, że może się o nią ubiegać autor, który w chwili wydania książki nie przekroczył 35 lat. Tegoroczny laureatem został Radosław Kossakowski, autor książki pod tytułem: Budda w kulturze konsumpcji.

Referatom, rozmowom i dyskusjom otwartej sesji Komitetu Nauk Pedagogicznych Polskiej Akademii Nauk przyświecała nie tyle myśl na te- 
mat tego, jak prowadzić (nie prowadzić) badania pedagogiczne, ale przede wszystkim refleksja nad tym, co jest ich siła, a co słabością. Uczestnicy obrad próbowali odkrywać te obszary ich działalności naukowej, które mogą podnieść poczucie satysfakcji z udziału w rozwoju pedagogiki. W tej nadziei prof. zw. dr hab. Bogusław Śliwerski, przewodniczący Komitetu Nauk Pedagogicznych Polskiej Akademii Nauk, zapowiedział, że na następną otwartą sesję zostaną zaproszeni dziekani Wydziałów Pedagogicznych wyższych uczelni. 
